\title{
Assessing the Impact of Land Use Policy on Urban-Rural Sustainability Using the FoPIA Approach in Yogyakarta, Indonesia
}

Hannes Jochen König ${ }^{1, *}$, Johannes Schuler ${ }^{1}$, Utia Suarma ${ }^{2}$, Desmond McNeill ${ }^{3}$, Jacques Imbernon ${ }^{4}$, Frieta Damayanti ${ }^{2}$, Syarifah Aini Dalimunthe ${ }^{2}$, Sandra Uthes ${ }^{1}$, Junun Sartohadi ${ }^{2}$, Katharina Helming ${ }^{1}$, Jake Morris ${ }^{5}$

1 Leibniz-Centre for Agricultural Landscape Research (ZALF), Eberswalder Str. 84, 15374 Müncheberg, Germany; E-Mails: jschuler@zalf.de (J.S.); suthes@zalf.de (S.U.); khelming@zalf.de (K.H.)

2 Gadjah Mada University (GMU), Bulaksumur, Sekip Utara Jalan Kaliurang Bulaksumur, Yogyakarta 55281, Indonesia; E-Mails: utiasuarma@ugm.ac.id (U.S.); frietadamayanti@gmail.com (F.D.); syarifah.dalimunthe@gmail.com (S.A.D.); panyidiksiti@yahoo.com (J.S.)

3 Centre for Development and the Environment (SUM), University of Oslo, P.O. Box 1116, Blindern, 0317 Oslo, Norway; E-Mail: desmond.mcneill@sum.uio.no

4 Centre de coopération internationale en recherche agronomique pour le développement (CIRAD), Avenue Agropolis, 34398 Montpellier Cedex 5, France; E-Mail: imbernon@cirad.fr

5 Forest Research, Alice Holt Lodge, Farnham, Surrey GU10 4LH, UK;

E-Mail: jake.morris@forestry.gsi.gov.uk

* Author to whom correspondence should be addressed; E-Mail: hkoenig@zalf.de;

Tel.: +49-33432-82-245; Fax: +49-33432-82-223.

Received: 2 June 2010 / Accepted: 19 June 2010 / Published: 5 July 2010

Abstract: This paper presents the results of a sustainability impact assessment (SIA) of policy induced land use changes in Yogyakarta, Indonesia. The regional problems include rapid expansions of urban areas, due to high population pressure, and the conversion of paddy fields and forests into settlements. The objective of this study was to assess the impacts of two land use policies on social, economic, and environmental Land Use Functions (LUFs) in Yogyakarta. The following scenarios were developed for the SIA: a forest protection scenario (S1), a paddy field conservation scenario (S2), and a counterfactual (no policy) scenario of 'Business As Usual' (BAU). The Framework for Participatory Impact Assessment (FoPIA) was applied to conduct an expert-based impact 
assessment. For the specification of the regional sustainability context, a set of nine key LUFs and associated indicators were developed, including three social, three economic, and three environmental sustainability criteria. The resulting scenario impacts of the assessment differed considerably, with positive impacts of the S1 and S2 scenarios on seven of nine LUFs, and negative impacts of the BAU scenario on six LUFs. The perception of the FoPIA method by the regional stakeholders was positive. We conclude that this method contributes toward an enhanced regional understanding of policy effects and sustainability, particularly in data-poor environments.

Keywords: sustainability impact assessment (SIA); land use change, land use functions (LUFs); stakeholder participation

\section{Introduction}

Sustainability oriented policy making requires a comprehensive and reliable analysis of the ex ante impacts of policy changes on the economic, environmental, and social components of development [1-3]. Sustainability Impact Assessment (SIA) is an increasingly accepted way for ex ante policy assessment and is rapidly spreading at different levels of governance [4,5]. A wide range of approaches is available in the field of SIA, including both analytical (e.g., model based), qualitative, and participation-based methods [6,7]. However, the specific context of policy making, together with the specific set of sustainability issues, makes every impact assessment unique and prohibits the development of "one size fits all" methods of impact assessment [2]. Because of complex interdependencies and abstract thinking in SIA, a suitable mix of contextually adapted approaches and tools should be considered that together, can support a sound and informed political decision-making. The choice of a particular approach for impact assessments depends on various aspects, such as the specific decision context, regional aspects, preferences of stakeholders and decision makers, capacities, budget, and the time available for the assessment. In many developed countries, for example, monitoring systems for environmental and socio-economic data have been established several decades ago, thus allowing the application of quantitative, computer-based assessment approaches.

However, data limitations still occur, for example, with regards to the availability of spatial land use data [8]. In addition, particularly if applied in multi-stakeholder contexts, SIA should not only include the provision of hard scientific facts, but should also be participatory and stakeholder-based in order to provide useful and transparent information to assist responsible decision making [9]. In this context, stakeholders are individuals, groups, and organizations that are directly affected by decisions and actions, or that have the power to influence the outcomes of these decisions [10].

In contrast, in many developing countries, the situation requires new research strategies in order to understand fundamental interactions between nature and society [11,12]. According to Bacic et al. [13], incomplete information is one of the main constraints for decision-making. Limited data availability and data quality often prevent the use of model-based assessments. This is particularly the case in developing countries and requires instead, softer approaches and more flexibility for SIA [14]. Indonesia serves as an appropriate example for the application of a participation-based SIA, where 
global changes and regional development have affected many urban and rural areas during the past. The chosen case study, Yogyakarta, has experienced vast land use changes that were mainly caused by urban expansions, high population pressures, and growing demands for natural resources.

Population density in the Yogyakarta region increased by $84 \%$ from 532 inhabitants per $\mathrm{km}^{2}$ in 1970 to 979 person per $\mathrm{km}^{2}$ in 2000 [15]. This rapid growth resulted in urban-rural expansions of built-up areas by 13\% (1990-2006) [16]. Given the fact that most natural forests in this region have been cleared already (with the remaining area being under strong protection), the demand for settlement space is mostly met by changing rice paddies into settlements. As observed by Ding [17] for another region, the loss of one unit of farmland due to urban constructions has to be reclaimed somewhere else (i.e., protected forests).

These developments brought about a set of policy actions on the agenda of national and regional legislation bodies with the aim of limiting the uncontrolled land use changes in the Region of Yogyakarta. However, such policies usually aim at one objective only, and do not take into account the sustainability impacts through side effects on other land uses and related sectors.

In this paper, we describe how the Framework for Participatory Impact Assessment (FoPIA) method, as developed by Morris et al. [18], was adapted to assess two relevant land use policies in the Region of Yogyakarta. We include a presentation of the results of the first application and a critical reflection upon testing this method in a non-European region for the first time.

\section{The Study Area}

The study was conducted in the Region of Yogyakarta (Figure 1). Yogyakarta is a densely populated area which is situated in Central Java, Indonesia, and is threatened by two main factors: high population pressure and frequently occurring natural hazards. High migration rates and economic growth have resulted in fast growing urban-rural expansion, mainly by land conversions from farmland and forest land into built-up areas [19]. The main economic activities refer to the service sector, agriculture, and industries, contributing to $39.6 \%, 15.1 \%$, and $13.9 \%$ of the regional gross domestic product (GDP), respectively [15].

The Region of Yogyakarta is comprised of five districts, with Bantul District in the south $\left(506.86 \mathrm{~km}^{2}\right)$, Sleman District in the north $\left(574.82 \mathrm{~km}^{2}\right)$, Kulon Progo District in the west $\left(586.27 \mathrm{~km}^{2}\right)$, Gunung Kidul District in the east $\left(1,485.36 \mathrm{~km}^{2}\right)$, and Yogyakarta City in the center $\left(32.5 \mathrm{~km}^{2}\right)$.

The northern part of Yogyakarta reaches the foothills of the Merapi volcano, which is considered one of the most active volcanoes in the world [20]. The last big eruption was dated back to 2006, which resulted in dramatic devastation of the Sleman and Bantul Districts, along with the suburbs of Yogyakarta City [21].

The elevation of the Region of Yogyakarta reaches 2,968 $\mathrm{m}$ above sea level. The climate is tropical, with average temperatures of $26.5^{\circ} \mathrm{C}$ and a high mean annual rainfall of approximately $1,855 \mathrm{~mm}$. 
Figure 1. Location map of the case study area of Yogyakarta, Indonesia, including the administrative boundaries of districts.

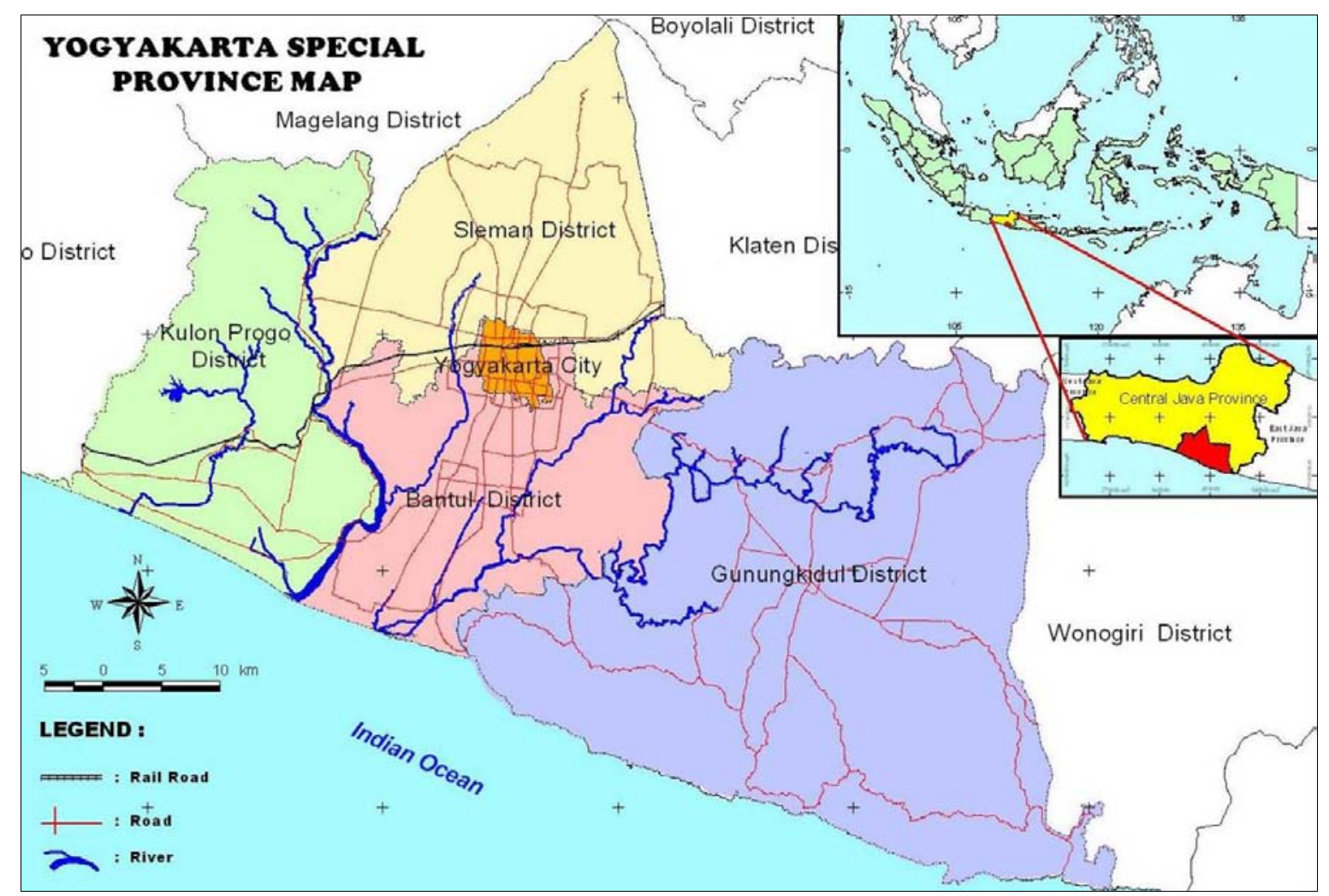

The region is characterized by industries in Yogyakarta City and small-scale subsistence agriculture in the suburban and rural areas.

From 1993 to 2006, urban built-up areas and new rural settlements doubled, while the area of agricultural land decreased by 25\%. Rural areas, including home- or forest gardens, now account for $16 \%$, and urban areas for $4 \%$. The remaining area belongs to forests and coastal protection zones [16].

Mixed farming systems with crop production, livestock, and home gardens (agroforestry systems) are the dominant farm types. These include paddy rice (Oryza sativa), mixed agroforestry systems with fruit trees, such as mango (Mangifera indica), banana (Musa x paradisiaca), and guava, and vegetables, including tomato (Solanum lycopersicum), chilli (Capsicum annuum), sweet potato (Ipomoea batatas), and cassava (Manihot esculenta), or annual crops, such as maize (Zea mays), beans (Phaseolus vulgaris), or groundnuts (Arachis hypogaea) under rainfed conditions. The livestock encompasses sheep, goats, beef cattle, dairy cows, and poultry.

\section{Methods}

\subsection{The FoPIA Approach}

For the SIA of the selected land use policies, we applied the FoPIA approach, as described by Morris et al. [18]. The FoPIA is a stand-alone method that can be used to structure and conduct an expert-based SIA. The implementation of the FoPIA to the study area of Yogyakarta followed an integrated approach, as proposed by Reidsma et al. [22], and was structured into three parts: (i) scenario development, (ii) specification of the sustainability context, and (iii) scenario impact 
assessment (Figure 2). During a preparation phase, available information and materials were gathered and evaluated with a focus on the case study region and related problem issues. Several expert workshops were first used to select potential policy instruments and drivers of regional land use changes to be developed into plausible and alternative future scenarios. For the specification of the regional sustainability context, we applied the Land Use Functions (LUF) concept $[3,23,24]$ that allows for a balanced classification of key sustainability issues into economic, social, and environmental assessment groups. For this purpose, a regional stakeholder workshop was used to identify and define a key set of LUFs and related assessment indicators. The impact assessment was then conducted, in which the scenario impacts were judged and discussed for each LUF. We considered stakeholders as being rather indirectly affected by the selected policies, including representatives of those stakeholders being involved in the design and implementation of a policy (experts at the regional level) and experts who provide knowledge and insights on the local impacts (land use changes). The involvement of stakeholders from different levels in the process of SIA was stressed by Fraser et al. [25] in order to avoid the neglection of either sustainability aspects. The research team facilitated as a moderator during the FoPIA workshop and was responsible for the evaluation and analysis of assessment results.

Figure 2. The implementation structure of the Framework for Participatory Impact Assessment (FoPIA) to the case study of Yogyakarta.

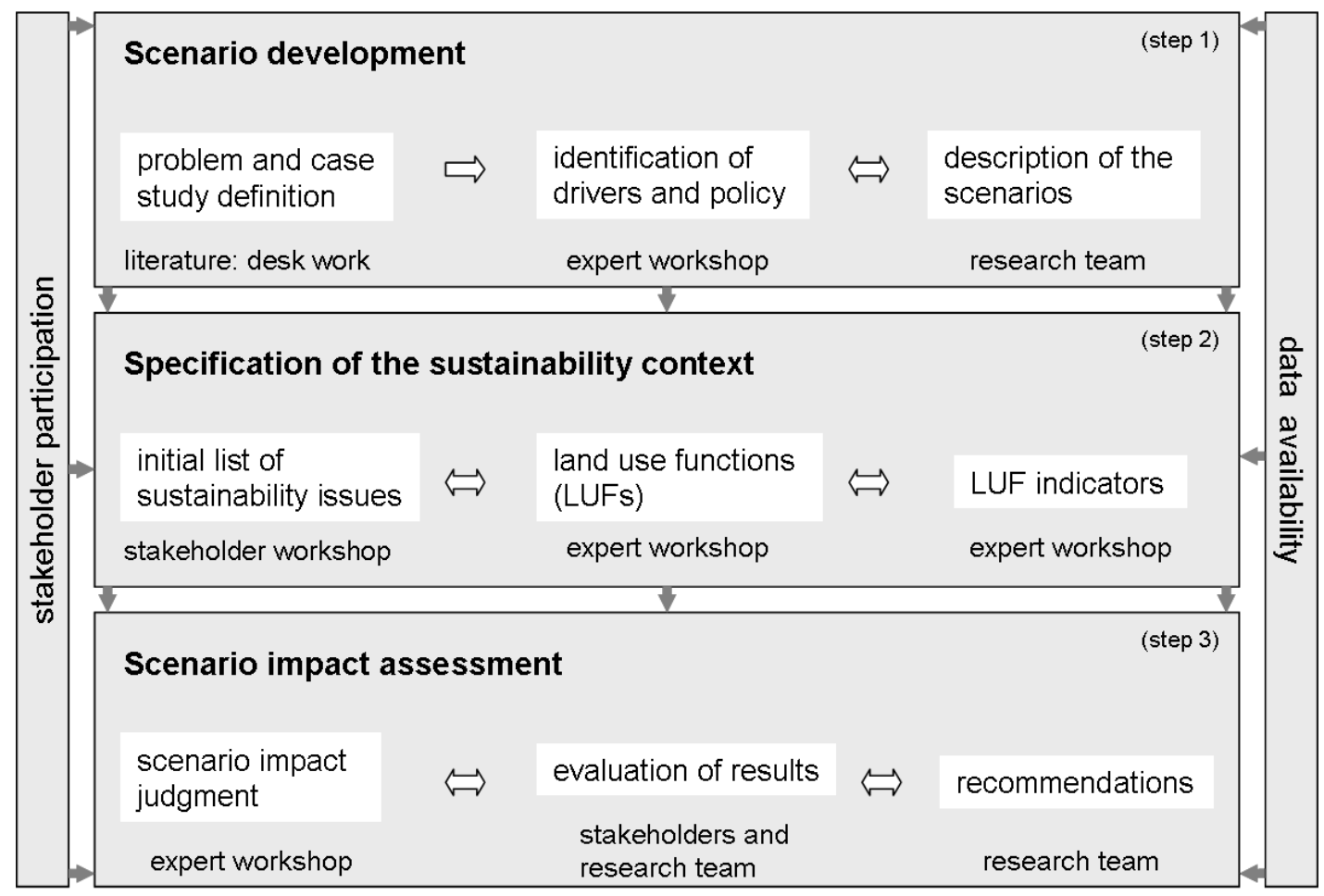

\subsection{Stakeholder Involvement}

Stakeholder knowledge was used to obtain the required expertise and judgment about policy impacts on regional LUFs. For this purpose, a group of fourteen regional actors was identified and invited to conduct an expert-based SIA of selected land use policies in Yogyakarta. The expert panel included representatives of the Agricultural Agency of Yogyakarta (one expert), Bureau of Forestry (one expert), Bureau of Environmental Management of Central Java (one expert), Department 
of Natural Hazards (UGM) (two experts), Department of Hydrology (UGM) (two experts), Spatial Planning Agency of Yogyakarta (one expert), Spatial Planning Agency of Sleman District (one expert), Spatial Planning Agency of Bantul District (one expert), Spatial Planning Agency of Kulon Progo District (one expert), Spatial Planning Agency of Gunung Kidul District (one expert), and the NGO of Rural Development (PUDSEA) (two experts). The group covered representatives from different regional, environmental, social, and economic institutions, and was limited to a group size of not more than 15 experts to allow for active knowledge exchange during discussions.

\subsection{Scenario Development}

The definition of the case study specific problem issues and the driving forces behind these problems, as well as the delineation of the case study boundaries, were completed in the first step of the scenario development. This first step was carried out by using available literature and materials from previous studies and available project reports. The selection of relevant land use policies was done during a prior expert workshop, in which local officials outlined the main characteristics and regional implementation of relevant land use policies. Based on these findings, we developed two alternative scenarios as follows: (1) S1, protection of forest land and (2) S2, conservation of paddy fields. We also used a 'Business As Usual' (BAU) scenario that served as a counterfactual scenario to assess scenario impacts in the absence of the policies (Table 1). For all three scenarios, the year 2025 was chosen as the target year, since we intended to focus on medium-term sustainable development impacts.

The S1 scenario had the goal of promoting forest areas and controlling illegal logging for environmental protection and economic development. Key scenario elements included a strong implementation of regional forest management and an increase of forest land by setting incentives on tree planting in rural areas and by promoting industrial timber production with high economic values (e.g., teak) and forest protection on upstream areas of watersheds and steep slope areas.

The S2 scenario aimed at the conservation of paddy fields with the main objective of ensuring regional food security. For the S2 scenario, we assumed a controlled and limited spread of settlements with key scenario elements that included a strong protection of paddy fields, incentives on paddy field farming through subsidized seedlings and fertilizer, and strong regulations and high taxing on land conversion.

The BAU scenario implied that land conversions continue as an ongoing trend, and that no additional or particular policy intervention was assumed. Simple land use maps were prepared to visualize possible scenario outcomes based on past land use changes and future trend extrapolations. For this purpose, the land use change modulator IDRISI was used to simulate changes of land use from 1993 to 2006 and projections toward 2025. 
Table 1. Description of the scenarios.

\begin{tabular}{llll}
\hline & BAU-Business As Usual & S1-Forest scenario & S2-Paddy field scenario \\
\hline $\begin{array}{l}\text { Scenario type } \\
\text { General characteristics }\end{array}$ & reference scenario & policy scenario & policy scenario \\
no policy (trend) & protection of forest land & protection of paddy fields \\
& economic growth, & economic growth, & economic growth, \\
Target year & population growth & population growth & population growth \\
& 2025 & 2025 & 2025 \\
Implementation & - & since 1999, full & since 1992, full \\
& & implementation from & implementation from \\
Instrument & - & 2009-2025 & 2009-2025 \\
\hline
\end{tabular}

\subsection{Land Use Functions and Indicators}

As mentioned above, the concept of LUFs [3] is applied within the FoPIA in order to link land use and sustainability. LUFs are defined as 'goods and services', which are provided by different land uses that summarize the most relevant economic, social, and environmental aspects of a region [23]. The framework of the LUFs is applied to classify regionally relevant sustainability issues into social, economic, and environmental categories, and to display interim SIA results as the basis for stakeholder discussions. In this regard, LUFs can be seen as a pragmatic method for stakeholder-driven sustainability assessment of land use changes [26]. To initiate a discussion of regional sustainability, a drafted set of LUFs was presented to the stakeholder group during the FoPIA workshop. In order to have an estimate for the regional importance of sustainability, a scoring exercise was used in which stakeholders were asked to point out their individual preferences on each LUF. The range of scores was from 1 to 10, where 10 denoted a very high importance and 1 denoted low importance. Scores were not exclusive, and could be attributed to more than one LUF. Scoring results were presented to stimulate discussions about different sustainability perceptions and to explore preferences for each LUF. Upon completion of this exercise and guided discussions of scoring results, the group was encouraged to move towards a shared understanding of the relative importance of each LUF. Based on these findings, a final list of nine region-specific LUFs was defined.

Each LUF needs to be represented by one corresponding indicator, as recommended by Morris et al. [18], in order to have a precise criterion for handling the LUFs in the impact assessment. These indicators were selected and defined by local experts and the research team.

Selection criteria for appropriate indicators were as follows:

1. the indicator should be relevant to the corresponding LUF,

2. the indicator should be clear and understandable,

3. the indicator should be as precise as possible and measurable,

4. the indicator should not be redundant to other indicators.

\subsection{Scenario Impact Assessment}

For the impact assessment, stakeholders assigned impact scores for each LUF indicator and corresponding scenario. It should be mentioned that the following scoring steps are not meant to be 
used in a statistical sense, but rather as a communication tool to support knowledge exchange and to stimulate discussions about possible scenario impacts. A scoring scheme from -3 to +3 was used to reflect, respectively, significant negative or positive impacts with the following scores: $0=$ no impacts; -1 and +1 few impacts; -2 and +2 high impacts; and -3 and +3 extremely high impacts. On completion of the individual scoring, average impact scores for each scenario on each LUF indicator were calculated (to one decimal point) and presented to the stakeholder group. The group was asked to discuss the average scores and the various arguments behind the individual impact scoring results. To initiate a discussion, the research team highlighted the contrasting positive and negative scoring results on each LUF and corresponding scenario. After exchange of arguments and open discussions, a second scoring round was undertaken in which experts could adjust the scores of the first scoring round. The arguments were summarized and reported by the research team, and the results were adjusted upon common agreement of the group. The workshop concluded with a summary presentation of the workshop results and a final discussion. Stakeholders were given the opportunity to give final comments on the impact assessment results.

\section{Results and Discussion}

\subsection{Land use Functions and Indicators of Yogyakarta}

The identification of LUFs started prior to the FoPIA workshop with a brain-storming session by the local research team, in which the European LUFs framework [23] was adjusted towards the regional sustainability context of Yogyakarta.

As a result of this adaptation process, a set of nine key LUFs were defined for the region of Yogyakarta. For each sustainability dimension, we identified the following LUFs (see also Table 2):

- Social land use functions: provision of work, quality of life, and food security;

- Economic land use functions: non-land-based activities, land-based production, and infrastructure;

- Environmental land use functions: provision of abiotic resources, provision of biotic resources, and maintenance of ecosystem processes.

The LUFs required some modifications with particular regard to the different cultural attitudes and sustainability targets of the Region of Yogyakarta compared to European regions. The major changes were considered for the social dimension in which the two LUFs, quality of life and food security, were newly introduced from the perspective of a developing country. Although the social LUFs are closely dependent on economic aspects, they reflect the main social attributes of the region of Yogyakarta, with respect to basic subsistence needs (food security) and livelihood (quality of life and employment). In contrast, the economic LUFs mainly cover aspects of economic growth (e.g., more roads and transportation systems, intensified agricultural production systems) and related structural changes (i.e., increase in built-up areas). Environmental LUFs refer to basic ecological functions (e.g., provision of natural goods, such as fresh water supply) and natural processes (an intact ecosystem: e.g., undisturbed water cycle and natural succession processes). 
Table 2. Land use functions (LUFs) and assessment indicators of Yogyakarta.

\begin{tabular}{|c|c|c|c|c|}
\hline \multicolumn{2}{|r|}{ Land use function (LUF) } & LUF relevance to & $\begin{array}{l}\text { Average score } \\
\text { (regional }\end{array}$ & LUF-indicator \\
\hline \multirow{3}{*}{. } & $\begin{array}{l}\text { 1. Provision of work: provision of } \\
\text { job opportunities for all in } \\
\text { activities based on natural } \\
\text { resources and related secondary } \\
\text { sectors (e.g., agriculture, } \\
\text { forestry, processing industries) }\end{array}$ & $\begin{array}{l}\text { Land use policies } \\
\text { significantly affect } \\
\text { land-based employment } \\
\text { opportunities [28,29]. }\end{array}$ & 7.86 & $\begin{array}{l}\text { regional employment } \\
\text { rate [\%] }\end{array}$ \\
\hline & $\begin{array}{l}\text { 2. Quality of life: an improved } \\
\text { livelihood and a fulfilled } \\
\text { minimum standard of living that } \\
\text { enables a longer life expectancy } \\
\text { (e.g., healthcare, education, } \\
\text { time for recreation, improved } \\
\text { housing facilities) }\end{array}$ & $\begin{array}{l}\text { Life expectancy is a } \\
\text { major attribute of } \\
\text { improved quality of life } \\
\text { [30-32]. }\end{array}$ & 7.79 & life expectancy [age] \\
\hline & $\begin{array}{l}\text { 3. Food security: sufficient quality } \\
\text { and quantity of food available to } \\
\text { meet the minimum daily needs } \\
\text { for human life; food should } \\
\text { either be produced locally or } \\
\text { imported from other regions }\end{array}$ & $\begin{array}{l}\text { Ensuring food security is } \\
\text { the first concern of rural } \\
\text { society }[33,34] \text {. }\end{array}$ & 8.79 & $\begin{array}{l}\text { food availability } \\
\text { [kg per capita/ year] }\end{array}$ \\
\hline \multirow{3}{*}{ 弟 } & $\begin{array}{l}\text { 4. Non-land based activities: } \\
\text { including residential and land } \\
\text { independent production systems, } \\
\text { provision of space where } \\
\text { residential; social and } \\
\text { productive human activity takes } \\
\text { place in a concentrated mode } \\
\text { (e.g., settlements, industries, } \\
\text { and urban areas) } \\
\end{array}$ & $\begin{array}{l}\text { Built-up areas reflect } \\
\text { economic development } \\
\text { situation in Central Java } \\
{[28,29,35] \text {. }}\end{array}$ & 8.50 & $\begin{array}{l}\text { land area used by } \\
\text { built-up areas } \\
\text { [GDP output/region] }\end{array}$ \\
\hline & $\begin{array}{l}\text { 5. Land-based production: land } \\
\text { that is used for production } \\
\text { activities which do not result in } \\
\text { irreversible change; e.g., } \\
\text { agriculture or forestry }\end{array}$ & $\begin{array}{l}\text { The majority of the local } \\
\text { population is involved in } \\
\text { agricultural production } \\
\text { [36,37]. }\end{array}$ & 7.64 & $\begin{array}{l}\text { land used for crop- } \\
\text { and economic } \\
\text { production } \\
\text { [km²/region] }\end{array}$ \\
\hline & $\begin{array}{l}\text { Infrastructure: road networks, } \\
\text { railways, and public transport, } \\
\text { involving a development that is } \\
\text { largely irreversible }\end{array}$ & $\begin{array}{l}\text { Transportation to link the } \\
\text { region with outside } \\
\text { areas [35]. }\end{array}$ & 8.14 & $\begin{array}{l}\text { road density } \\
\text { [km length/region] }\end{array}$ \\
\hline
\end{tabular}


Table 2. Cont.

\begin{tabular}{|c|c|c|c|c|}
\hline \multicolumn{2}{|r|}{ Land use function (LUF) } & $\begin{array}{c}\text { LUF relevance to } \\
\text { Yogyakarta }\end{array}$ & $\begin{array}{c}\text { Average score } \\
\text { (regional } \\
\text { importance) }\end{array}$ & LUF-indicator \\
\hline \multirow{3}{*}{ 률 } & $\begin{array}{l}\text { 7. Provision of abiotic resources: } \\
\text { the role of land in regulating the } \\
\text { supply of water }\end{array}$ & $\begin{array}{l}\text { Water availability is a } \\
\text { basic natural resource } \\
\text { [38]. }\end{array}$ & 8.00 & $\begin{array}{l}\text { water availability } \\
{\left[\mathrm{m}^{3} / \text { region] }\right.}\end{array}$ \\
\hline & $\begin{array}{l}\text { 8. Provision of biotic resources: } \\
\text { factors affecting the capacity of } \\
\text { the land to support the provision } \\
\text { of abiotic resources and } \\
\text { ecosystem processes }\end{array}$ & $\begin{array}{l}\text { Protected land is a main } \\
\text { indicator for an improved } \\
\text { environment [39]. }\end{array}$ & 7.71 & $\begin{array}{l}\text { natural land under } \\
\text { protection } \\
\text { [area size/region] }\end{array}$ \\
\hline & $\begin{array}{l}\text { 9. Maintenance of ecosystem } \\
\text { processes: the role of natural } \\
\text { cleaning processes to supply } \\
\text { clean and fresh water }\end{array}$ & $\begin{array}{l}\text { Clean water is a major } \\
\text { development target } \\
{[28,40] \text {. }}\end{array}$ & 8.14 & clean water $\left[\mathrm{m}^{3}\right]$ \\
\hline
\end{tabular}

The selected assessment indicators for each LUF were the following (Table 2): employment rate, life expectancy, food availability per capita, size of built-up areas, land used for crop and economic production, road density, water availability, area size of natural land, and water quality.

Results of the scoring exercise of stakeholders' perceptions towards the regional importance of each LUF (Table 2) revealed that food security (8.79), non-land based activities (8.50), infrastructure (8.14), the provision of abiotic resources (e.g., water availability) (8.00), and the maintenance of ecosystem processes (e.g., provision of clean water) (8.14) appeared to be most important in Yogyakarta. This seems to be reasonable because regional food production dropped as a result of conversions of crop-land to urban areas with consequences for regional food supply and self-sufficiency. Urban related LUFs were considered highly important for non-land based activities and infrastructure, since these two LUFs reflect the recent economic activities. The supply of clean water appeared to be a crucial aspect in the Yogyakarta region, due to high urbanization rates and lagging sanitation systems. These sanitation systems are considered a general problem of fast growing cities in developing countries [27]. In contrast to this, provision of work (7.86), quality of life (7.79), land-based production (7.64), and the provision of biotic resources (7.71) were scored to be less important, as indicated by lower scoring results. Stakeholder opinions brought forward stated that urban areas provide new job opportunities and better access to education and health care systems. These qualities were believed to improve the quality of life. With urban-rural land conversions, land-based production was scored less important, since urban areas provide new economic opportunities to rural society. The protection of natural land was scored as less important because the current priorities for sustainable development were given on urban and economic development issues. 


\subsection{Stakeholder-Based Scenario Impact Assessment}

\subsubsection{BAU scenario impacts}

The provision of work was seen as a way of improving under the BAU scenario (impact score +1.7; Table 3). The main argument brought forward by the stakeholders was that the rapid economic growth, particularly in the urban areas of Yogyakarta, will provide new job opportunities to the local people. The close relationship between economic growth and employment was also observed, for example, by Firman [41]. However, it was mentioned that most of the new jobs created would be primarily run by migration workers and therefore, would be less available for local people. The negative impacts on quality of life for health issues (impact score -1.2) were expected, due to the increasing risk of natural disasters, such as landslides and floods, as a result of ongoing and uncontrolled land conversions (builtup and deforestation). Some stakeholders and a study by Hidajat [32] saw possible improvements to handle such health threats via higher education. A common agreement that is also reported by several studies (e.g., [27,33,34]) was that ongoing land conversions of crop-land into build up areas put local food security at a high risk (impact score -2.1). However, a positive aspect mentioned in this regard was the likely introduction of new and improved technologies (e.g., high yielding varieties and fertilizers) that would increase the land productivity and food output per land unit.

Table 3. Scenario impact assessment results based on stakeholder judgements.

\begin{tabular}{lcccccc}
\hline Land use function & \multicolumn{2}{c}{ BAU } & \multicolumn{2}{c}{ S1 } & \multicolumn{2}{c}{ S2 } \\
& Mean & min/max & mean & min/max & mean & min/max \\
\hline Provision of work & 1.7 & $3 /-2$ & -0.1 & $2 /-2$ & 0.9 & $3 /-2$ \\
Quality of life & -1.2 & $1 /-2$ & 1.8 & $3 / 0$ & 1.8 & $3 / 0$ \\
Food security & -2.1 & $2 /-3$ & 0.4 & $3 /-3$ & 2.5 & $3 / 1$ \\
Non-land based activities & 1.8 & $3 /-1$ & 0.4 & $3 /-2$ & 0.1 & $3 /-2$ \\
Land-based production & -2.0 & $3 /-3$ & -0.1 & $3 /-3$ & 1.7 & $3 /-3$ \\
Infrastructure & 1.5 & $3 /-3$ & 0.4 & $3 /-2$ & 0.5 & $3 /-2$ \\
Provision of abiotic resources & -2.1 & $-1 /-3$ & 2.2 & $3 / 0$ & 0.1 & $3 /-3$ \\
Provision of biotic resources & -2.2 & $-1 /-3$ & 2.0 & $3 /-1$ & -0.1 & $3 /-3$ \\
Maintenance of ecosystem processes & -2.2 & $0 /-3$ & 1.9 & $3 /-1$ & -0.6 & $3 /-3$ \\
\hline
\end{tabular}

The non-land-based development was considered to improve during the coming years, due to high economic growth in Yogyakarta (impact score +1.8) (e.g., [16,28,35]). Nevertheless, it was mentioned that the increasing development of settlements in the most developed district of Yogyakarta (Sleman District) towards the Merapi volcano would bring a higher risk for possible drawbacks and urban devastations due to natural hazards. The stakeholders' impact scores for the land-based production ranged from -3 to +3 , with different underlying arguments, but with negative scenario impacts on average (impact score -2.0). The main negative arguments were that agriculture will experience dramatic losses of productive land due to high land conversion rates and the fast expansion of urban areas into rural regions. This argument was also supported by Hadiprayitno [33] and Herlina [34]. Positive arguments referred to improved and intensified agricultural practices that may be 
reasonable if new techniques will be introduced [41]. With regard to infrastructure, developments were expected to be positive (impact score +1.5 ), and the main argument was that the government, due to Yogyakarta's rapid economic development, will increase investments into road and transportation projects [35]. Again, some stakeholders mentioned that natural hazards may cause serious damage to high-risk development sites, particularly in those which are close to the Merapi volcano.

The provision of abiotic resources, including a guaranteed supply of natural water resources, was shown to experience serious regional problems [28] with a high negative impact score (-2.1). The main argument was that illegal forest logging in the headwater catchments caused by increasing population pressure and higher demands for natural resources will dramatically increase. Although water availability was not considered an issue during the past, because of high regional rainfall, increasing demand for water resources and a continuing disturbance of natural water systems became a major concern nowadays. Similar negative impacts were also seen on the provision of biotic resources (natural and protected areas), with a negative impact score of -2.2 , and on the maintenance of ecosystem processes (impact score -2.2). It was argued that land conversions and increasing establishments of urban settlements on mountainous upstream areas causes land degradation (landslides) and water pollution, with related loss of natural land (see, e.g., [40]). In addition to the mainly negative arguments on all environmental functions (impact scores from -3 to 0 ), it was stated that rural people may become more aware of their environment through negative experiences, training, and education (see e.g., [32]), and because of this, locals may handle natural resources more sustainably in the future.

\subsubsection{S1 scenario impacts (forest protection)}

The average scoring impacts of the S1 scenario on the provision of work were slightly negative $(-0.1$; Table 3$)$. However, the range of given scores was wide $(-2$ to +2$)$. The negative impact scores were mainly based on the opinion that forest land, which is usually under protection, will not provide employment possibilities. The positive argument referred to a forest protection program, called 'GERHAN', which is run by the government, and to the expansion of industrial forest plantations for teak production that provide some job opportunities to the region. Quality of life was considered to perform positively under the S1 scenario (impact score +1.8 ). The most common opinion was that forest land will reduce the risk of natural disasters, such as landslides or floods [42], and hence limit the danger for human life. Based on the opinion that large areas of forest land will be used as integrated agroforestry systems or so-called household gardens, the corresponding scoring argument for food security (impact score +0.4 ) was positive on average. These combined agriculture-forest systems have a long tradition in the Region of Yogyakarta [43] and provide various fruit products, such as mango, papaya, coconut, banana, and other tropical fruits.

Non-land-based production was expected to increase (impact score +0.4 ), based on the general trends of the BAU scenario and the assumption that non-land-based production is intensified due to the shift of agriculture activities to more off-farm activities in the service and industry sectors. This development trend was considered to of benefit for the overall economic development $[29,36]$. Land-based production was predicted to decline (impact score -0.1) and was underpinned by the argument that regional land use develops towards more urban and related built-up areas in the 
surroundings of Yogyakarta City [29]. Infrastructure was expected to progress further in development through structural changes and government investments [28,29].

The provision of abiotic and biotic resources and the maintenance of ecosystem processes were all seen to improve under the S1 scenario (impact scores of $+2.2,+2.0,+1.9$, respectively). The main arguments behind these impact scores were that the conservation of forest land will contribute toward the fulfilment of key ecosystem processes. For example, forest land will stabilize hydrological functions at watershed level including water infiltration into the soil and related groundwater recharge, and provide natural filtering mechanisms for fresh water [42].

\subsubsection{S2 scenario impacts (paddy field conservation)}

The provision of work was scored to improve under the S2 scenario (impact score +0.9 ; Table 3). The main argument mentioned by the stakeholders was that the Region of Yogyakarta, as a national food bowl for rice production [19], has a long tradition of agriculture. Agriculture has always provided work to rural society. Some stakeholders, however, raised their concerns about paddy field cropping because agriculture activities and related economic returns may not held pace with the overall rapid economic growth in Yogyakarta, and many farmers tend to leave on-farm activities for alternative off-farm jobs [29,41]. Quality of life was expected to perform positively under the S2 scenario (impact score +1.8 ). The common opinion was that paddy fields, if properly managed, may reduce the risk of landslides and floods, and hence limit the risk of natural disasters on human health. The food security situation was believed to improve if paddy fields will be maintained and their productivity increased through technological innovations [33,34].

On average, the non-land-based production, based on the opinion that alternative off-land sectors, such as industries and services are intensified [28], was thought to slightly increase (impact score +0.1 ). The land-based production was expected to increase (impact score +1.7 ); this opinion was underpinned by the argument that regional paddy field production is intensified and supported towards national food security. Infrastructure was expected to create some developmental progress through governmental construction programs (impact score 0.5 ), which link remote rural regions to other areas.

The provision of abiotic resources was expected to slightly improve (impact score of +0.1 ) on average, although scoring arguments were varied. To the stakeholders' opinion, paddy fields may have either effect on regional water availability. On the one hand, water resources are restored on paddy cultivations [44], but on the other hand, water is also intensively used for crop production and is less available for other uses. The provision of biotic resources and the maintenance of ecosystem processes were expected to slightly decline (impact scores of $-0.1,-0.6$, respectively). The common opinion was that paddy fields fulfill less natural functions when compared to those of natural land, and contribute to lower water quality, due to use of chemicals and fertilizers.

\subsection{Overall Performance of LUFs under the Three Scenarios}

Impacts of the BAU scenario resulted in negative impacts on two social LUFs (quality of life and food security), an economic LUF (land-based production), and all environmental LUFs. The provision of work (social LUF) and the economic LUFs, non-land based production and infrastructure, were 
assessed to improve. The scenario impact performance illustrates a positive impact result of the S1 scenario on seven out of nine LUFs, which particularly includes the environmental LUFs and excludes the social LUF, 'provision of work', and the economic LUF, 'land-based production'. Impacts of the S2 scenario were expected to have positive impacts on seven out of nine LUFs, which, in this case, particularly refer to the social and economic dimension and exclude the environmental LUFs, 'provision of biotic resources' and 'maintenance of ecosystem processes'. As an overall outcome, S2 showed the highest positive impacts on most LUFs compared to the BAU and S1 scenarios. Nevertheless, the two environmental LUFs, 'provision of biotic resources' and 'maintenance of ecosystem processes', were expected to experience negative impacts in the scenario S2.

The results of the stakeholder-based impact assessment were shown to be differentiated for each scenario. The general outcome seems to be plausible, although the impact arguments varied among workshop participants.

The general reasons behind the negative impacts on the environmental LUFs and related negative impacts on the quality of life appeared to be well understood by most stakeholders. The land conversion towards built-up areas appeared to be a major threat for regional land-based production, and consequently, land conversion affects food security. The positive performances of the economic LUFs, non-land based production and infrastructure, and the social LUF, provision of work, appeared to be reasonable, as a result of rapid economic development.

Under the S1 scenario, the social LUF, provision of work, was expected to experience negative impacts. Forest plantations and protected forest land were considered to provide only a few job opportunities that cannot supply sufficient job possibilities to a growing population size. The scenario S1 was considered to contribute to local food security through food harvests from agroforestry systems and forest gardens - whereas the economic output with regard to land-based production was considered to develop negatively. The social LUF, 'quality of life', and the environmental LUFs were all expected to improve by meeting the goals of soil and water conservation strategies.

The S2 scenario was expected to have negative impacts on two environmental LUFs ('provision of biotic resources' and 'maintenance of ecosystem processes'). Paddy field cultivation was considered to have rather negative effects on natural ecosystem processes and also contributes to water pollution. The positive performance of all social and economic LUFs appeared to be reasonable for the 'provision of work', 'quality of life', 'food security', and 'land-based production'. Impacts of the S2 scenario were assessed to be moderate on 'non-land based production' and 'infrastructure' as a result of some economic growth, and also slightly positive on the environmental LUF, 'provision of abiotic resources', as a result of water management strategies.

\subsection{Reflections on the FoPIA Approach}

From a methodological point of view, we want to point out some critical reflections on the FoPIA method and its transferability success to a tropical region in South-East Asia (i.e., Indonesia). The overall results of the impact assessment appeared plausible, and the reactions of the stakeholders involved in the assessment process allow us to conclude that a participation-based method is suitable for the context described. A particular advantage of the chosen FoPIA method is that in the absence of transparent monitoring and background data, the consultation of stakeholders from different 
backgrounds ensures that a wide range of information is gathered and the risk of overlooking important causal relationships is reduced.

After the FoPIA workshop, a team-internal evaluation by the participating expert group showed the following positive aspects: the FoPIA provides a well structured guideline to conduct an SIA, offers a high degree of transparency, produces quick results, and is a good approach for interdisciplinary knowledge exchange with regard to a better understanding of the sustainability concept. The stated negative aspects of this method referred to the limited number of indicators, complexity of scenarios, different sustainability issues, and limited time budget for some experts, as they had to spend a full day on the workshop. The quantification of results remains limited and instead, requires a more qualitative interpretation. The inclusion of social LUFs appeared to be crucial by revealing sensitive impact issues that were of particular importance to assessing urban-rural sustainability in an integrated way; however, a close link to economic LUFs remains.

Nevertheless, the FoPIA requires careful preparation, critical evaluation, and feedback communication of the final results. If FoPIA is used as a stand-alone method, it is recommended that one pay particular attention to the stakeholder selection process (i.e., ensure that a balanced and interdisciplinary selection is made) and to make enough time available to carefully discuss all scoring extremes and stakeholder arguments. In this study, we found it helpful to include local knowledge from different levels that supported and complemented the implementation of the SIA process; these actions allowed for a critical evaluation and reflection of the FoPIA results.

\section{Conclusions}

The intention of this study was to perform an SIA of two alternative land use policies by focusing not only on environmental issues, but also on social and economic aspects. We have chosen a qualitative impact assessment approach with quantitative elements using local stakeholder knowledge. The chosen approach proved to be useful in this particular assessment context, which is characterized by low data availability and the necessity of cross-disciplinary integration of knowledge.

The key outcomes of our study are therefore not only the assessed impact scores, but moreover the arguments behind them:

Firstly, the stakeholders generally believed that the conservation of forest land or paddy fields had rather positive impacts on most social and ecological land use functions in Yogyakarta, but some stakeholders also indicated that land-based production may not hold pace with overall economic development. In fact, many rural people tend to sell their land to receive ad hoc cash and may reorient to better paid off-farm jobs. This is supported by other studies and the fact that rural income sources, such as small-scale agriculture or eco-tourism alone, do not provide sufficient economic returns for larger population numbers.

Secondly, uncontrolled land conversion and natural hazards remain two major problem issues in Yogyakarta. On the one hand, high population pressure and increasing demand for land cause the cultivation of land at risky sites. On the other hand, unexpected natural disasters can set incentives for people to concentrate on specific sites, which often leads to uncontrolled land degradation. 
Recommendations drawn from our study are based on stakeholders' preferences and their scenario impact judgements and include the following:

- to ensure regional food security by maintaining and conserving paddy fields so as to supply sufficient food to the region,

- to allow for regional development, including built-up and infrastructure projects, but to carefully consider potential negative side effects and to establish spatial measures that monitor and control land conversions from rural to urban land use,

- to maintain key ecosystem processes by protecting remaining forest land, particularly in the headwater catchments of Yogyakarta, and thereby reduce the risk of landslides and floods,

- to promote integrated agroforestry systems and home gardens that should contribute to some local socio-economic benefits to rural society, while maintaining key environmental land use functions.

Further research should study more of the differentiated land conversion impacts on regional (i) water availability, (ii) profitability, and (iii) food security to inform decision makers and to improve land management practices at a regional level. On a methodological level, some practical issues should be considered: the definition of the optimal group size of stakeholders that should be included into the different steps of the SIA process, the design of policy and land use change scenarios, the identification and selection of appropriate sustainability indicators, and the determination of how much preparation is needed in order to make the workshop most effective, but at the same time, maintain stakeholder motivation. Furthermore, it remains to be seen whether the method itself can possibly serve as a decision support instrument for stakeholders, or whether the exercise remains on an academic level. For future applications, this ambiguity needs to be worked on, so as to clearly make use of this tool. FoPIA has a high potential to guide stakeholders' discussions, throughout an impact assessment, towards the different dimensions of sustainability.

It should be kept in mind that the FoPIA puts the most emphasis on the impact assessment procedure itself and the 'participatory' process of impact discussions on each of the scenarios and 'affected' indicators. These potentials need to be sharpened while the deficiencies need to be reconsidered and further developed for future applications.

\section{Acknowledgements}

The authors wish to thank the EU-funded LUPIS project (Land Use Policies and Sustainable Development in Developing Countries); EU FP6 STREP Project-Priority Area 1.1.6.3 ("Global Change and Ecosystems”) for providing methodological insight into participatory and integrated impact assessments. We would also like to thank the stakeholders and experts of the Region of Yogyakarta who provided their knowledge about land use policy experiences and impacts on rural sustainability and development. 


\section{References}

1. Pope, J.; Grace, W. Sustainability assessment in context: Issues of process, policy and governance. J. Environ. Assess. Policy Manage. 2006, 8, 373-398.

2. Scrieciu, S.S. The inherent dangers of using computable general equilibrium models as a single integrated modelling framework for sustainability impact assessment. A critical note on Bohringer and Loschel (2006). Ecol. Econ. 2007, 60, 678-684.

3. Helming, K.; Bach, H.; Dilly, O.; Hüttl, R.; König, B.; Kuhlmann, T.; Pérez-Soba, M.; Sieber, S.; Smeets, P.; Tabbush, P; etc. Ex ante impact assessment of land use changes in European regions-The SENSOR approach. In Sustainability Impact Assessment of Land Use Changes; Helming, K., Pérez-Soba, M., Tabbush, P., Eds.; Springer: Berlin, Germany, 2008; pp. 77-105.

4. George, C.; Kirkpatrick, C. Assessing national sustainable development strategies: Strengthening the links to operational policy. Nat. Resour. Forum 2006, 30, 146-156.

5. De Ridder, W.; Turnpenny, J.; Nilsson, M.; Von Raggamby, A. A framework for tool selection and use in integrated assessment for sustainable development. J. Environ. Assess. Policy Manage. 2007, 9, 423-441.

6. Rotmans, J. Methods for IA: The challenges and opportunities ahead. Environ. Model. Assess. 1998, 3, 155-179.

7. Hacking, T.; Guthrie, P. A framework for clarifying the meaning of Triple Bottom-Line, Integrated, and Sustainability Assessment. Environ. Impact Assess. Rev. 2002, 28, 73-89.

8. Schmit, C.; Rousevell, M.D.A.; La Jeunesse, I. The limitations of spatial land use data in environmental analysis. Environ. Sci. Policy 2006, 9, 174-188.

9. Thabrew, L.; Wiek, A.; Ries, R. Environmental decision making in multi-stakeholder contexts: Applicability of life cycle thinking in development planning and implementation. J. Cleaner Prod. 2009, 17, 67-76.

10. Freeman, E.R. Strategic Management: A Stakeholder Approach; Pitman: Boston, MA, USA, 1984.

11. Kates, R.W.; Clark, W.C.; Corell, R.; Hall, J.M.; Jaeger, C.C.; Lowe, I.; McCarthy, J.J.; Schellnhuber, H.J.; Bolin, B.; Dickson, N.M.; etc. Environment and development-Sustainability science. Science 2001, 292, 641-642.

12. Lambin, E.F.; Turner, B.L.; Geist, H.J.; Agbola, S.B.; Angelsen, A.; Bruce, J.W.; Coomes, O.T.; Dirzo, R.; Fischer, G.; Folke, C.; etc. The causes of land-use and land-cover change: Moving beyond the myths. Global Environ. Change 2001, 11, 261-269.

13. Bacic, I.L.Z.; Bregt, A.K.; Rossiter, D.G. A participatory approach for integrating risk assessment into rural decision-making: A case study in Santa Catarina, Brazil. Agr. Syst. 2006, 87, 229-244.

14. Uthes, S.; Fricke, K.; König, H.; Zander, P.; van Ittersum, M.; Sieber, S.; Helming, K.; Piorr, A.; Müller, K. Policy relevance of three integrated assessment tools-A comparison with specific reference to agricultural policies. Ecol. Model. 2010, in press.

15. Propinsi DIY Dalam Angka (1970-2007); Biro Pusat Statistik: Yogyakarta, Indonesia, 2008.

16. Sartohadi, J.; Widiyatmoko, D.S.; Mei, E.W. D3.1-Overview and Analysis of Land Use Policies in Indonesia; LUPIS, EU 6th Framework Programme, 2008; Available online: http://www.lupis.eu (accessed on 1 February 2010). 
17. Ding, C. Policy and planning challenges to promote efficient urban spatial development during the emerging rapid transformation in China. Sustainability 2009, 1, 384-408.

18. Morris, J.; Camilleri, M.; Moncada, S. Key sustainability issues in European sensitive areas-A participatory approach. In Sustainability Impact Assessment of Land Use Changes; Helming, K., Pérez-Soba, M., Tabbush, P., Eds.; Springer: Berlin-Heidelberg, Germany, 2008; pp. 451-470.

19. Dimyati, M.; Mizuno, K.; Kobayashi, S.; Kitamura, T. An analysis of land use/cover change using the combination of MSS Landsat and land use map-A case study in Yogyakarta, Indonesia. Int. J. Remote Sens. 1996, 17, 931-944.

20. Lavigne, F.; Thouret, J.C.; Voight, B.; Suwa, H.; Sumaryono, A. Lahars at Merapi volcano, Central Java: An overview. J. Volcanol. Geotherm. Res. 2000, 100, 423-456.

21. Charbonnier, S.J.; Gertisser, R. Field observations and surface characteristics of pristine block-and-ash flow deposits from the 2006 eruption of Merapi Volcano, Java, Indonesia. J. Volcanol. Geotherm. Res. 2008, 177, 971-982.

22. Reidsma, P.; König, H.; Feng, S.; Bezlepkina, I.; Nesheim, I.; Bonin, M.; Sghaier, M.; Purushothaman, S.; Sieber, S.; van Ittersum, M.K.; etc. Methods and tools for integrated assessment of land use policies on sustainable development in developing countries. Land Use Policy 2010, submitted.

23. Pérez-Soba, M.; Petit, S.; Jones, L.; Bertrand, N.; Briquel, V.; Omodei-Zorini, L.; Contini, C.; Helming, K.; Farrington, J.H.; Mossello, M.T.; etc. Land use functions-A multifunctionality approach to assess the impact of land use changes on land use sustainability. In Sustainability Impact Assessment of Land Use Changes; Helming, K., Pérez-Soba, M., Tabbush, P., Eds.; Springer: Berlin-Heidelberg, Germany, 2008; pp. 375-404.

24. Paracchini, M.L.; Pacini, C.; Jones, M.L.; Pérez-Soba, M. An aggregation framework to link indicators associated with multifunctional land use to the stakeholder evaluation of policy options. Ecol. Indic. 2009, in press.

25. Fraser, E.D.G.; Dougill, A.J.; Mabee, W.E.; Reed, M.; McAlpine, P. Bottom up and top down: Analysis of participatory processes for sustainability indicator identification as a pathway to community empowerment and sustainable environmental management. J. Environ. Manage. 2006, 78, 114-127.

26. Schößer, B.; Helming, K.; Wiggering, H. Assessing land use change impacts-A comparison of the SENSOR land use function approach with other frameworks. J. Land Use Sci. 2010, 5, 159-178.

27. Chen, J. Rapid urbanization in China: A real challenge to soil protection and food security. CATENA 2007, 69, 1-15.

28. Firman, T. Major issues in Indonesia's urban land development. Land Use Policy 2004, 21, 347-355.

29. Firman, T. Rural to urban land conversion in Indonesia during boom and bust periods. Land Use Policy 2000, 17, 13-20.

30. Adlakha, A.; Rudolph, D.J. Aging trends: Indonesia. J. Cross-Cult. Gerontol. 1994, 9, 99-108.

31. Abikusno, N. Sociocultural aspects of the aged: A case study in Indonesia. Asia Pac. J. Clin. Nutr. 2002, 11, S348-S350. 
32. Hidajat, M.M.; Hayward, M.D.; Saito, Y. Indonesia’s social capacity for population health: The educational gap in active life expectancy. Pop. Res.Policy Rev. 2007, 26, 219-234.

33. Hadiprayitno, I. Food security and human rights in Indonesia. Develop. Pract. 2010, 20, 122-130.

34. Herlina, L. Critical review on food security and policies towards poverty: The living experience of the Indonesian government. J. Agric. Rural Dev. Trop. Subtro. 2004, supplement 80, 81-86.

35. Kusago, T. Regional disparity in accessibility to non-farm economic involvement among rural Indonesian households. ASEAN Econ. Bull. 2002, 19, 290-301.

36. Steffan-Dewenter, I.; Kessler, M.; Barkmann, J.; Bos, M.M.; Buchori, D.; Erasmi, S.; Faust, H.; Gerold, G.; Glenk, K.; Gradstein, S.R.; etc. Tradeoffs between income, biodiversity, and ecosystem functioning during tropical rainforest conversion and agroforestry intensification. Proc. Nat. Acad. Sci. USA 2007, 104, 4973-4978.

37. Coomes, O.T.; Burt, G.J. Indigenous market-oriented agroforestry: Dissecting local diversity in western Amazonia. Agroforest. Syst. 1997, 37, 27-44.

38. Nickel, D.; Barthel, R.; Braun, J. Large-scale water resources management within the framework of GLOWA-Danube-The water supply model. Phys. Chem. Earth 2005, 30, 383-388.

39. Bawa, K.S.; Seidler, R. Natural forest management and conservation of biodiversity in tropical forests. Conserv. Biol. 1998, 12, 46-55.

40. Smith, G.D.; Wetselaar, R.; Fox, J.J.; van de Graaff, R.H.M.; Moeljohardjo, D.; Sarwono, J.; Asj'ari, W.S.R.; Tjojudo, S.; Basuki. The origin and distribution of nitrate in groundwater from village wells in Kotagede, Yogyakarta, Indonesia. Hydrogeol. J. 1999, 7, 576-589.

41. Firman, T. Labour allocation, mobility, and remittances in rural households: A case from Central Java, Indonesia. Sojourn 1994, 9, 81-101.

42. Bruijnzeel, L.A. Hydrological functions of tropical forests: Not seeing the soil for the trees? Agr. Ecosyst. Environ. 2004, 104, 185-228.

43. Palte, J. Upland mixed-garden agroforestry on Java, Indonesia. Neth. Rev. Dev. Stud. 1988, 2, 81-93.

44. Yoshikawa, N.; Shiozawa, S. Estimating variable acreage of cultivated paddy fields from preceding precipitation in a tropical watershed utilizing Landsat TM/ETM. Agr. Water Manage. 2006, 85, 296-304.

(C) 2010 by the authors; licensee MDPI, Basel, Switzerland. This article is an Open Access article distributed under the terms and conditions of the Creative Commons Attribution license (http://creativecommons.org/licenses/by/3.0/). 